Note: This is a pre-submission draft of the manuscript. It has not been peerreviewed and may be submitted for publication in a peer-reviewed journal in the near future. Subsequent versions of this manuscript may vary in content and length. If published, the final version will be included with a link on the peerreviewed publication doi page

Author Listing:

Huiru Xu ${ }^{1}$, Joseph G. Meert ${ }^{2}$, Manoj Pandit ${ }^{3}$

${ }^{1}$ Hubei Subsurface Multi-scale Imaging Key Laboratory, Institute of Geophysics and Geomatics, China University of Geosciences, Wuhan, China

${ }^{2}$ Department of Earth and Planetary Sciences, University of Florida, Gainesville, FL 32611

${ }^{3}$ Department of Geology, University of Rajasthan, Jaipur 302004, India 


\title{
A Short Note on the Age of the Marwar Supergroup, NW India
}

\author{
Huiru Xu${ }^{1}$, Joseph G. Meert ${ }^{2}$, Manoj Pandit ${ }^{3}$
}

${ }^{1}$ Hubei Subsurface Multi-scale Imaging Key Laboratory, Institute of Geophysics and Geomatics, China University of Geosciences, Wuhan, China

${ }^{2}$ Department of Earth and Planetary Sciences, University of Florida, Gainesville, FL 32611

${ }^{3}$ Department of Geology, University of Rajasthan, Jaipur 302004, India

\section{Introduction}

The age and evolution of the myriad Purana (ancient) basins in Peninsular India is a source of controversy primarily due to the lack of robust geochronological constraints (Meert and Pandit, 2015; Basu and Bickford, 2015; Lan et al., 2020). The Vindhyan and the Marwar Basins in Northcentral and NW India are particularly problematic in terms of their ages (Retallack et al., 2021; Lan et al., 2020; Malone et al., 2008; McKenzie et al., 2011; Turner et al., 2011; George and Ray, 2017; Ansari et al., 2018). This paper reports new geochronological results from a felsic volcanic layer in the basal part of the Marwar Supergroup. These data confirm previous suggestions that the Marwar Supergroup is post-Cryogenian in age. The presence of Early Cambrian trace fossils in the Nagaur sandstone coupled with the available ages indicate that deposition in the Marwar Basin can be reliably correlated to strata in the Krol-Tal (Himalayas), Salt Range (Pakistan) and Oman (McKenzie et al., 2011; Cozzi et al., 2012; Turner et al., 2013; Davis et al., 2014).

The Marwar Basin is located in NW India (Figure 1). It consists of an unevenly distributed group of outcrops in southern Rajasthan and is also known from drill core in the central and northern areas. The Marwar Supergroup is composed of three distinct packages known as the Nagaur, Bilara and Jodhpur Groups (youngest to oldest; Figure 2). The sediments rest unconformably over the Malani Rhyolite province. The Malani rocks are reliably dated to between 750-771 Ma using U-Pb methods (Gregory et al., 2008; Meert et al., 2013; Wang et al., 2017). The Malani province extends into neighboring Pakistan where the rocks are referred to as the Nagar-Parkar Igneous Complex. Recent geochronological data from Pakistan suggest that igneous activity was prolonged from 660-812 Ma (Markhand et al., 2017; Rehman et al., 2018; Shakar et al., 2019). Most of the data from Nagar Parkar is on the granitic rocks with only a single age of 767 Ma determined from volcanic rocks. Based on these data and the unconformable relationship 
between the Marwar Supergroup and the Malani igneous rocks, the age of Marwar sedimentation was generally taken to be younger than $660 \mathrm{Ma}$.

With the exception of reliable Cambrian trace fossils in the Nagaur sandstone (Kumar and Pandey, 2008, 2010; Srivastava, 2012; Singh et al., 2012), most of the body/trace fossils within the sequence lack reliable age control although they broadly assigned to the Ediacaran (Sharma et al., 2014 and references therein). The Ediacaran age for the entire Marwar Supergroup is also supported by the lack of glaciogenic rocks that might be expected if the basin was active during the Cryogenian interval (Meert and Pandit, 2015). Several authors have argued that the Pokaran boulder bed in the basal part of the Marwar is of glacial origin (Chauhan et al., 2001; Bhatt et al., 2005); however, Cozzi et al. (2012) and Davis et al. (2014) pointed out that the so-called glacial striations observed in the Sankra region are ventifacts and most of the boulders are well-rounded and locally derived.

Two recent papers proposed vastly different ages for the basal Sonia sandstone (George and Ray, 2017; Lan et al., 2020). George and Ray (2017) used Rb-Sr dating on a felsic volcanic layer near the top of the Sonia sandstone and suggested that Sonia deposition was older than $\sim 700$ Ma. George and Ray (2017) cited a preliminary 700 Ma age reported in an abstract by the current authors in support of their conclusion (Xu and Meert, 2014); however, at the time the abstract was submitted, the data had not been completely analyzed. The zircon that yielded the age reported in the abstract is more than $20 \%$ discordant and therefore unreliable. Lan et al. (2020) identified a single occurrence of a much younger detrital zircon below the felsic volcanics with an age of $\sim 617$ Ma. McKenzie et al. (2011) noted a single occurrence of a detrital zircon in the Nagaur sandstone with an age of $\sim 540 \mathrm{Ma}$. The bulk of the evidence favors a post-Cryogenian age for the Marwar sedimentation, but geochronological are sparse and single detrital zircon ages can be problematic for determining maximum depositional ages (Gehrels, 2011; Spencer et al., 2016).

We collected additional samples from the Chhoti Khatu volcanics to obtain a more robust age on this felsic unit. At this location, the Marwar sequence lies unconformably over deformed slates and phyllites of the Sirohi Supergroup (Paliwal, 1998; Figure 3). There is a basal conglomerate overlying the Sirohi metasediments followed by the maroon-colored sandstones and shales of the Sonia Formation. Paliwal (1998) described the overlying volcanic sequence as a basal rhyolite/pyroclastic unit with alternating layers of tuff followed by a shaly sandstone and a quartzose conglomerate. The Girbhakar Formation is developed on the top of the volcano- 
sedimentary sequence and is easily identifiable as a series of cross-bedded pebbly sandstones and sandstones. At our sampling location, we did not see any evidence for pyroclastic deposits, but rather a single thick felsic flow and several thin ash deposits. We collected samples from the purported ash layers and the thicker felsic volcanic deposit for $\mathrm{U}-\mathrm{Pb}$ geochronology (figure 3).

\section{Methods}

\section{CL imaging}

Zircons were isolated by conventional density and magnetic separation techniques, embedded in resin epoxy and polished to about half their thickness. Cathodoluminescence imaging was acquired on an EVO MA10 XVP at Department of Geological science (University of Florida, UFL) with an accelerating voltage of $12 \mathrm{kV}$ and a LEO1450VP scanning electronic microprobe at the institute of Geology and Geophysics (Chinese Academy of Sciences, CAS) with an accelerating voltage of $15 \mathrm{kV}$, respectively. Zircons from the Khatu sequence are granular to columnar, with sizes ranging from 30 to $100 \mu \mathrm{m}$. Most of the zircons are rounded. Brightness varied from dark to off-white with variable core-rim textures. Concentric zoning can be observed in a few grains (see figure 4).

\section{Geochronological analyses (University of Florida)}

For uranium, thorium and lead isotopic measurements, we used the "Nu-Plasma" $(\mathrm{Nu}$ Instruments, UK) multi-collector inductively coupled plasma mass spectrometer (LA-MC-ICPMS) attached to an Applied Spectra J200 $213 \mathrm{~nm}$ laser system in Department of Geological science (UFL). Before $\mathrm{U}-\mathrm{Pb}$ analyses, the epoxy plugs were sonicated and cleaned in nitric acid to remove any common $\mathrm{Pb}$ surface contamination. Then, the mounted zircons were ablated with a laser spot size of $20 \mu \mathrm{m}$ using a laser frequency of $10 \mathrm{~Hz}$ and $60 \%$ power. High-purity helium with flux of ca. $0.55 \mathrm{~L} / \mathrm{min}$ was used to carry the ablated material into the ICP-MS. The whole laser path was fluxed with Argon (ca. $1.1 \mathrm{~L} / \mathrm{min}$ ) to increase energy stability. Zircon samples were analyzed in runs of 12 analyses, which begin with 2 standard zircons (FC-1) and 10 samples points following. Spots were taken on both the rim and core of some zircons and recorded accordingly. U-Pb ages were calculated from the raw signal data using a Microsoft Excel ${ }^{\circledR}$ spreadsheet (Calamari). Figures were generated and errors calculated using IsoplotR plotting software by Vermeesch (2018, following Ludwig, 2008). Errors on the ${ }^{207} \mathrm{~Pb} /{ }^{235} \mathrm{U}$ and ${ }^{206} \mathrm{~Pb} /{ }^{238} \mathrm{U}$ ratios are reported at the 2 sigma (\%) level and ages are reported at the 1-sigma level (Table 1). 
Geochronological analyses (Institute of Geology and Geophysics China Academy of Sciences)

Cameca IMS 1280 SIMS at the institute of Geology and Geophysics (CAS) was utilized for U-Pb dating. The mounts were vacuum-coated with high purity gold prior to SIMS analysis. The size of ion beam was $10 \times 15 \mu \mathrm{m}$. During the analysis, the standard zircon Plešovice (Sláma et al., 2008) was used to calibrate the $\mathrm{Pb} / \mathrm{U}$ ratio. Measured compositions were corrected for common lead using non-radiogenic ${ }^{204} \mathrm{~Pb}$. An average present-day crustal composition (Stacey and Kramers, 1975) is used for the common $\mathrm{Pb}$ assuming that the common $\mathrm{Pb}$ is largely surface contamination introduced during sample preparation. More details for calibration methods refer to Li et al. (2009). Uncertainties for individual analyses (ratio and ages) are at the $1 \sigma$ level. Raw SIMS U-Pb zircon data are reduced using the Cameca IMS 1280 HR built-in software CIPS. Figures were generated and errors calculated using IsoplotR plotting software by Vermeesch (2018; following Ludwig, 2008). Errors on the ${ }^{207} \mathrm{~Pb} /{ }^{235} \mathrm{U}$ and ${ }^{206} \mathrm{~Pb} /{ }^{238} \mathrm{U}$ ratios and ages are reported at the 1 sigma (\%) level (Table 2)

\section{Results}

We required that acceptable zircon ages were both $<15 \%$ discordance in ${ }^{206} \mathrm{~Pb} /{ }^{238} \mathrm{U}$ vs ${ }^{207} \mathrm{~Pb} /{ }^{206} \mathrm{~Pb}$ ages and $<10 \%$ discordant based on the log-ratio distance (LRD) between the measured composition and the single grain concordia composition (Vermeesch, 2021; Tables 1 \& 2). A total of 68 zircon spots met these requirements. Figures $5 \mathrm{a}, \mathrm{b}$ show all the analyses for each spot and a kernel density/histogram plot of the measured LRD concordia ages (figure 5c). Lan et al. (2020) reported 363 zircon spots from the Sonia sandstone and a kernel density/histogram plot for those data is shown in figure $5 \mathrm{~d}$ for comparison. We applied the same filter to the Lan et al. (2020) data which eliminated 3 of their analyses. The distributions are dominated by peaks in the $800-900$ Ma range. Our Khatu sample shows a similar, but subdued profile likely due to the smaller number of analyses. The oldest zircon in our collection was $\sim 2560 \mathrm{Ma}$ and the youngest zircon was $651+/-9 \mathrm{Ma}$ (age from ash-layer \#3; Figures 4 and 5a).

\section{Discussion}


While it was long assumed that sedimentation in the Marwar basin was confined to the Neoproterozoic, precise age constraints on the depositional history are still sparse (see Chakrabarti et al., 2004 and references therein). Radiometric attempts to date the Marwar Supergroup rest entirely on the ages of detrital zircons within the sequence. The first reported age for the Khatu felsic rocks was made by George and Ray (2017) who obtained a five-point whole rock $\mathrm{Rb}-\mathrm{Sr}$ age of $703+/-40 \mathrm{Ma}$. Although the authors argued for minimal disturbance of the $\mathrm{Rb}$-Sr system, there is a large spread of ${ }^{87} \mathrm{Rb} /{ }^{86} \mathrm{Sr}$ ratios that seems inconsistent with a rather homogenous and thin outcrop ( 1 m thick).

Lan et al. (2020) collected a large sample of material from various localities within the Sonia sandstone including the Khatu location and reported a youngest zircon from the Sonia sandstone at $<616 \mathrm{Ma}$. While not materially changing their conclusions, we re-evaluated their zircon data using the methods outlined in Vermeesch (2021). Three zircons in the Sonia sandstone yield concordant ages of $624+/-4.1,624+/-4.3$ and $622+/-7.0 \mathrm{Ma}$. Our youngest zircon from one of the ash layers at Khatu yields an age of $651+/-9 \mathrm{Ma}$. While the data are still limited from the Sonia sandstone, they do support a post-Cryogenian age for the onset of Marwar sedimentation. The youngest Malani effusive rocks are dated to $\sim 750 \mathrm{Ma}$ although there is evidence for intrusive activity in nearby Pakistan as young as $643 \mathrm{Ma}$. Therefore, the unconformity between the Malani rhyolites and the Sonia sandstone spans $\sim 125 \mathrm{Ma}$. Locally, the unconformity may be shorter or longer such as at Chhoti Khatu where the Marwar sequence overlies Sirohi metamorphic rocks.

\section{Conclusions}

Although direct dating of the Marwar Supergroup has proven elusive and the age of sedimentation is contentious, recent efforts have significantly narrowed the range of possibilities. Previous detrital zircon studies along with stable isotopic excursions favor a post-Cryogenian age for the sequence. The felsic volcanic unit at Chhoti Khatu was previously dated using $\mathrm{Rb}-\mathrm{Sr}$ methods (George and Ray, 2017) at 700 Ma. That age was challenged by Lan et al. (2020) who discovered zircons as young as $\sim 622 \mathrm{Ma}$ within the Sonia sandstone at the same location. Our study also favors a younger age as we have a zircon from one of the ash beds dated at $651+/-9$ Ma. While the data are still limited, we argue that Marwar sedimentation started shortly after the end of the Marinoan glaciation near the Cryogenian/Ediacaran boundary and continued into the early Cambrian. Robust ages from the Malani Igneous Province indicates a hiatus of $\sim 125 \mathrm{Ma}$ 
between the end of Malani volcanism and deposition of the Sonia sandstone. There are indications of younger magmatism across the border in Pakistan at least as young as $643 \mathrm{Ma}$. The felsic volcanics and ash beds preserved at Chhoti Khatu may therefore represent volcanism near the Cryogenian/Ediacaran boundary associated with the assembly of Gondwana (Meert, 2003).

Acknowledgements: The authors would like to thank blah, blah blah. Funding for this research was provided to JGM by the US National Science Foundation Grant EAR09-10888. The conclusions of this article reflect those of the authors and not of the funding agency.

\section{$\underline{\text { References Cited }}$}

Ansari, A.H., Pandey, S.K., Sharma, M., Agrawal, S., Kumar, Y., 2018. Carbon and oxygen isotopic stratigraphy of the Ediacaran Bilara Group, Marwar Supergroup, India: Evidence for high amplitude carbon isotopic negative excursions, Precambrian Research, 308, 75-91.

Basu A, Bickford M.E., 2015. An alternate perspective on the opening and closing of the Intracratonic Purana Basins in Peninsular India. Journal Geological Society India, 85, 5-25.

Bhatt, D.K., Prasad, S., Jain., R.L., Mathur, A.K., 2005. Some critical field observations on the genesis and stratigraphical status of the Pokaran boulder beds, Western Rajasthan, Journal of the Geological Society of India, 65, 301-308.

Chakarabarti, C., Pyne, T.K., Gupta, P., Basu-Mallik, S., Guha, D., 2004. A Manual of the Geology of India. Part IV: Northern and Northwestern Part of the Peninsula, v. 77, Geological Survey of India Special Publication, $257 \mathrm{pp}$.

Cozzi, A., Rea, G., Craig, J., 2012. From global geology to hydrocarbon exploration: Ediacaran-Early Cambrian petroleum plays of India, Pakistan and Oman, Geological Society of American Special Publication, 366, doi:10.1144/SP366.14.

Davis, J.K., Meert, J.G., Pandit, M.K., 2014. Paleomagnetic analysis of the Marwar Supergroup, Rajasthan, India and proposed interbasinal correlations, Journal of Asian Earth Sciences, 91, 339-351.

George, B.G. and Ray, J.S., 2017. Provenance of sediments in the Marwar Supergroup, Rajasthan, India: implications for basin evolution and Neoproterozoic global events, Journal of Asian Earth Sciences, 147, 254-270.

Gerhels, G., 2011. Detrital zircon U-Pb geochronology: Current methods and new opportunities, in: Busby, C. and Azor, A. (eds) Tectonics of Sedimentary Basins: Recent Advances, Wiley, NY, pp. 45-62.

Gregory, L.C., Meert, J.G., Bingen, B., Pandit, M.K., Torsvik, T.H., 2008. Paleomagnetic and geochronologic study of Malani Igneous Suite, NW India: implications for the configuration of Rodinia and the assembly of Gondwana, Precambrian Research, 170, 13-26.

Kumar, S. and Pandey, S.K., 2008. Discovery of trilobite trace fossils from the Nagaur sandstone, the Marwar Supergroup, Dulmera area, Bkianer District, Rajasthan, Current Science, 94, 1081-1085. 
Lan, Z., Zhang, S., Li, X-H, Pandey, S.K., Sharma, M., Shukla, Y., Ahmad, S., Sarkar, S., Zhai, M., 2020. Towards resolving the 'jigsaw puzzle' and age-faunal inconsistency within East Gondwana, Precambrian Research, 345, doi:10.1016/j.precamres.2020.105775

Li, X.-H., Liu, Y., Li, Q.-L., Guo, C.-H., Chamberlain, K.R., 2009. Precise determination of Phanerozoic zircon $\mathrm{Pb} / \mathrm{Pb}$ age by multicollector SIMS without external standardization. Geochem., Geophys., Geosyst. 10.

Ludwig, K.R., 2008. Manual for Isoplot 3.7: Berkeley Geochronology Center. Special Publication No. 4.

Malone, S.J., Meert, J.G., Banerjee, D.M., Pandit, M.K., Tamrat, E., Kamenov, G.D., Pradhan, V.R., Sohl, L.E., 2008. Paleomagnetism and detrital zircon geochronology of the Upper Vindhyan sequence, Son Valley and Rajasthan, India: A ca. 1000 Ma closure age for the Purana basins? Precambrian Research, 164, 137159

Markhand, A.H., Xia, Q., Agheem, M.H., Jia, L., 2017. U-Pb zircon dating and geochemistry of the rocks at Washrai body, Nagar Parkar Igneous Complex, Sindh, Pakistan, Sindh University Research Journal, 49, 16.

McKenzie, N.R., Hughes, N.C., Myrow, P.M., Xiao, S., Sharma, M., 2011. Correlation of Precambrian-Cambrian sedimentary sequences across northern India and the utility of isotopic signatures of Himalayan lithotectonic zones, Earth and Planetary Science Letters, 312, 471-483.

Meert, J.G., 2003. A synopsis of events related to the assembly of eastern Gondwana, Tectonophysics, 362, 1-40.

Meert, J.G. and Pandit, M.K., 2015. Precambrian Evolution of Peninsular India and its Link to Basin evolution, in: Eriksson et al. (eds) Geological Society of London, Special Publication \#43, Precambrian Basins of India: Stratigraphic and Tectonic Criteria, pp. 29-54.

Paliwal, B.S., 1998. Felsic volcanics interlayered with sediments of the Marwar Supergroup at Chhoti Khatu District, Nagaur, Rajasthan, Journal of the Geological Society of India, 67, 709-714.

Pareek, H.S., 1984. Pre-Quaternary geology and mineral resources of north-western Rajasthan, Memoirs Geological Society of India, 115, 1-99.

Rehman, H.U., Khan, T., Jan, M.Q., Lee, H-Y, Chung, S-L., Murata, M., 2018. Timing and span of the continental crustal growth in SE Pakistan: Evidence from LA-ICP-MS U-Pb zircon ages from granits of the Nagar Parkar igneous complex, Gondwana Research, 61, 172-186.

Rettalack, G.J., Matthews, M.A., Master, S., Khangar, R.G., Khan, M., 2021. Dickinsonia discovered in India and late Ediacaran biogeography, Gondwana Research, 90, 165-170.

Sláma, J., Košler, J., Condon, D.J., Crowley, J.L., Gerdes, A., Hanchar, J.M., Horstwood, M.S.A., Morris, G.A., Nasdala, L., Norberg, N., Schaltegger, U., Schoene, B., Tubrett, M.N., Whitehouse, M.J., 2008. Plešovice zircon - A new natural reference material for $\mathrm{U}-\mathrm{Pb}$ and $\mathrm{Hf}$ isotopic microanalysis. Chem. Geol. 249, 135 .

Shakar, M.A., Yang, Y., Deng, J., Hakro, A.A.A.D., 2019. Early Neoproterozoic evolution of SE Pakistan: evidence from geochemisty, geochronology and isotopic composition of the Nagar Parkar igneous complex, International Geology Review, 61, 1391-1408.

Sharma, M., Pandey, S.K., Kumar, S., 2014. International field workshop on the Marwar Supergroup, Rajasthan, western India: Field Guide, Society of Earth Scientists, Lucknow, India, 80 pp.

Spencer, C.J., Kirkland, C.L., Taylor, R.J.M., 2016. Strategies towards statistically robust interpretations of in-situ $\mathrm{U}-\mathrm{Pb}$ zircon geochronology, Geoscience Frontiers, 7, 581-589. 
Srivastava, P., 2012. Trepichnus pedum: An ichnofossil representing Ediacaran-Cambrian boundary in the Nagaur Group, the Marwar Supergroup, India., Proceedings of the National Science Academy, 78, 9-17.

Stacey, J.S., Kramers, J.D., 1975. Approximation of terrestrial lead isotope evolution by a two-stage model. Earth Planet. Sci. Lett. 26, 207-221.

Turner, C.C., Meert, J.G., Pandit, M.K., Kamenov, G.D., 2014. A detrital zircon U-Pb and Hf isotopic transect across the Son Valley sector of the Vindhyan basin, India: Implications for basin evolution and paleogeography, Gondwana Research, 26, 348-364.

Vermeesch, P., 2018. IsoplotR: A free and open toolbox for geochronology, Geoscience Frontiers, 9, 1479-1493.

Vermeesch, P., 2021 On the treatment of discordant detrital zircon U-Pb data, Geochronology, 3, 247-257, doi:10.5194/gchron-3-247-2021.

Xu, H. and Meert, J.G., 2014. New U-Pb zircon ages from Khatu rhyolites in the Jodhpur Group, India: constraints on the lower age limit for the Marwar Supergroup, AGU Fall Meeting Abstracts, p. 3560.

\section{Figure Legends}

Figure 1: Map of the Marwar Supergroup in western Rajasthan. White areas of the map are quaternary sands (after Pareek, 1984).

Figure 2: Generalized stratigraphy of the Marwar Supergroup in Rajasthan. Shown are the approximate stratigraphic levels for the youngest detrital zircons, fossils and the proposed location for the Ediacaran-Cambrian boundary based on stable isotopes (Pandey et al., 2018).

Figure 3: Stratigraphic column at the Chhoti Khatu sampling site. Stars represent the sampling levels for geochronology and the youngest zircon age is listed for each sampled level. Bottom: Photo of the contact between the Sonia siltstone and the Chhoti Khatu volcanics.

Figure 4: Cathodoluminescent photographs of selected grains from this study. Sample numbers, spot location and concordant ages are also listed (see Table 1).

Figure 5: (a) Wetherill concordia diagram for the 68 zircon spots in the Chotti Khatu outcrop for grains with ages between 650-2000 Ma; (b) Paleoproterozoic and Neoarchean analyses from Chotti Khatu; (c) Kernel density and histogram plot for the Khatu samples (25 Ma bandwidth) and (d) Kernel density and histogram plot for Sonia sandstone samples from the study by Lan et al. (2020; 25 Ma bandwidth) for comparison. 


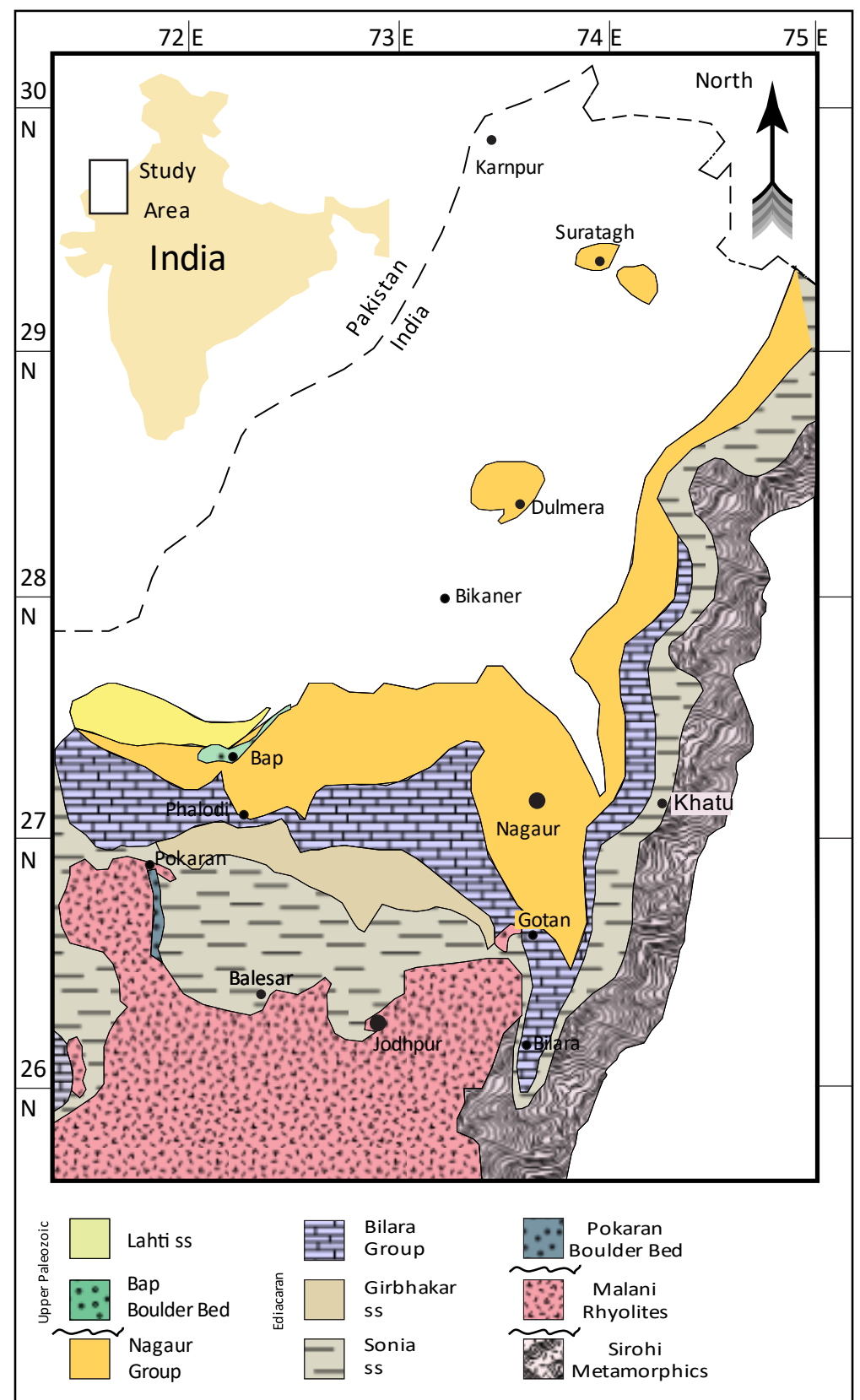

Figure 1 


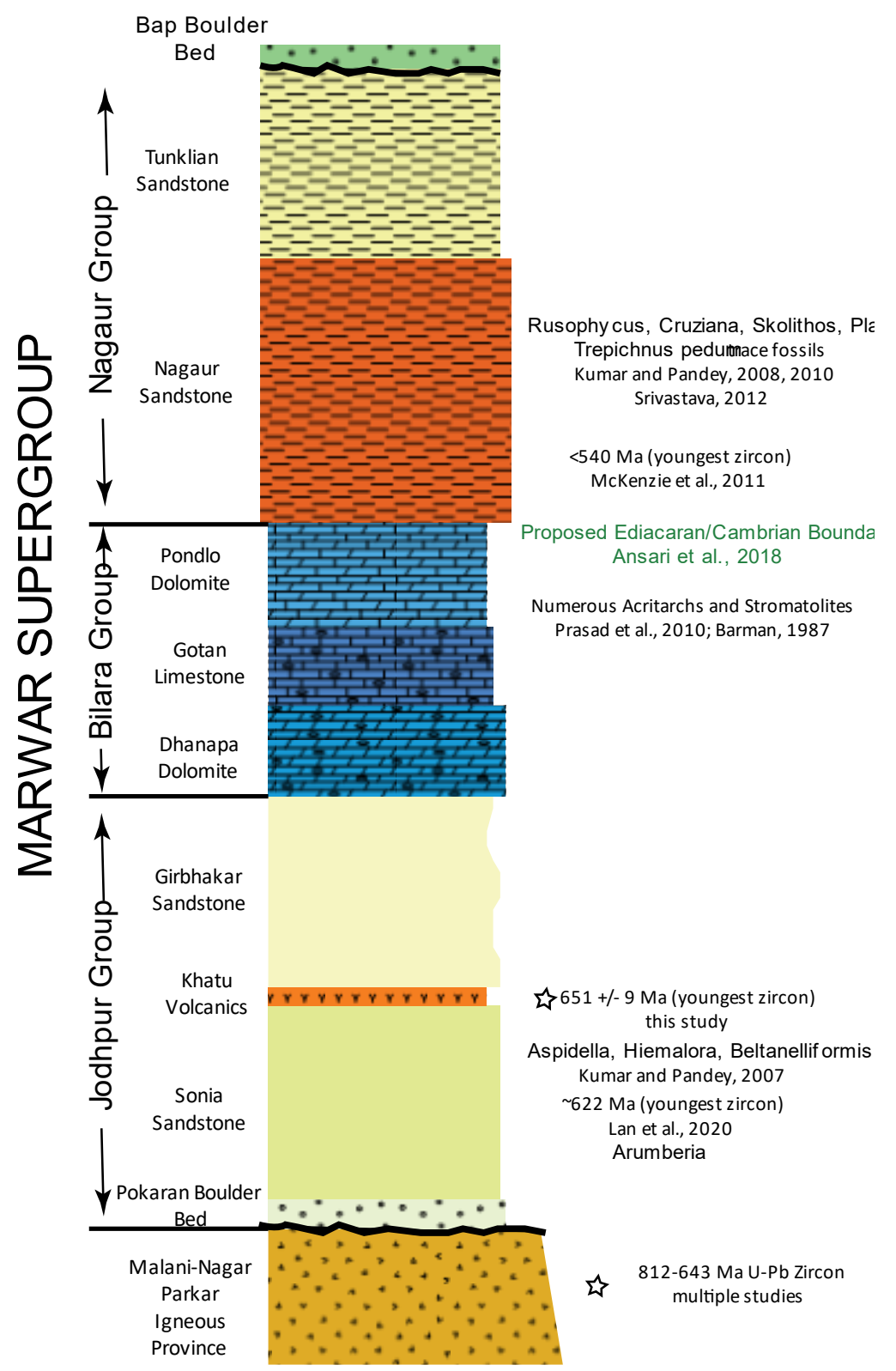

Figure 2. 


\section{Chhoti-Khatu Section}
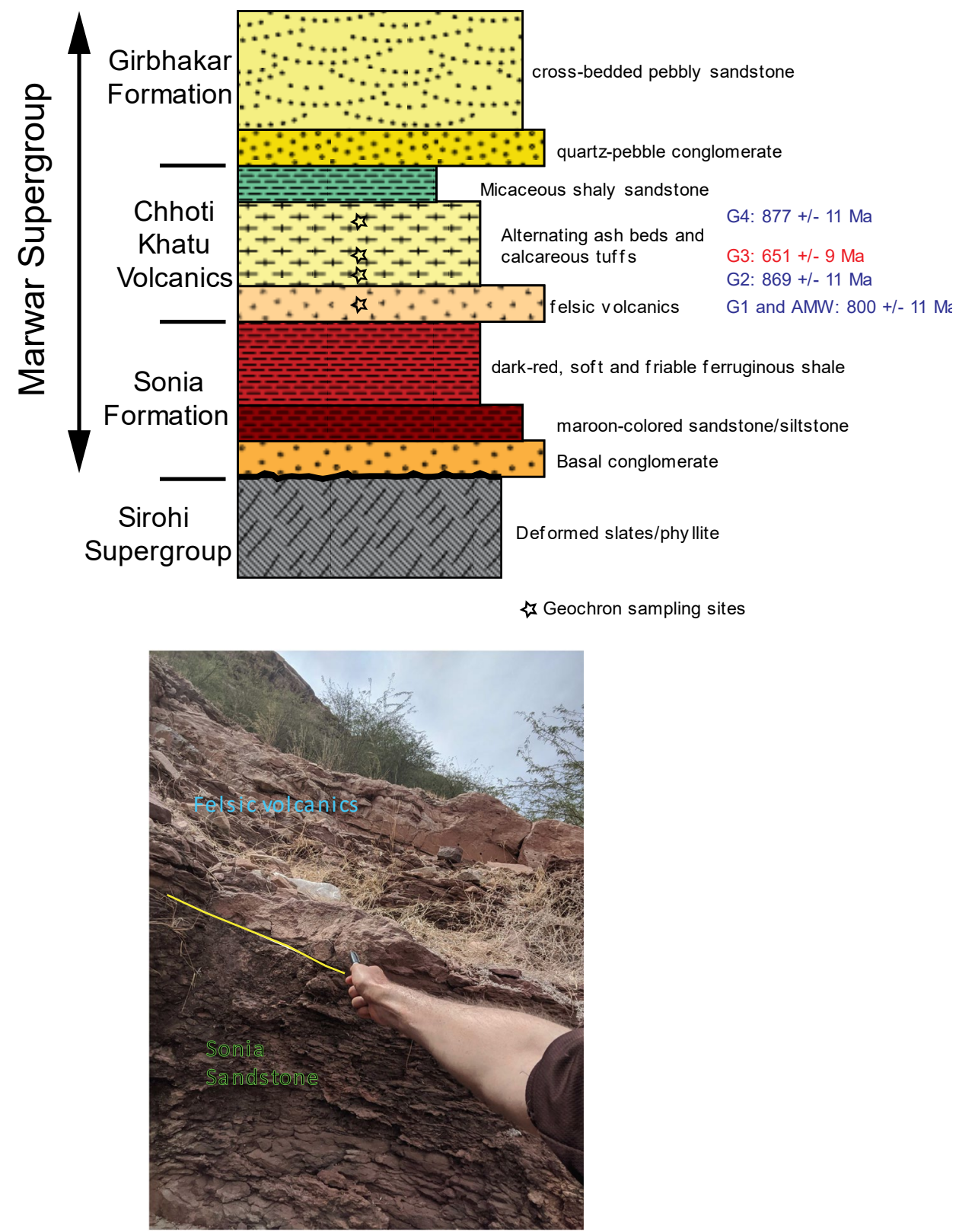

Figure 3. 


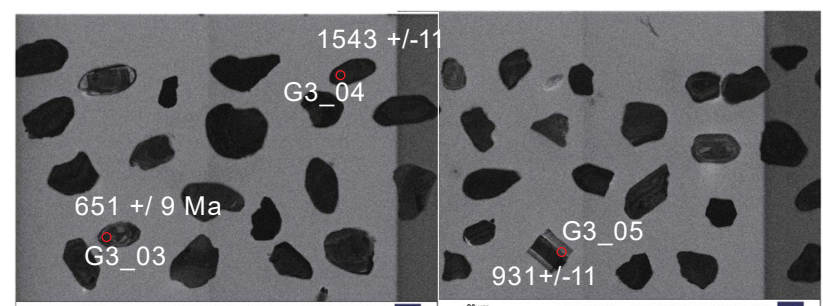

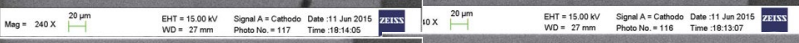
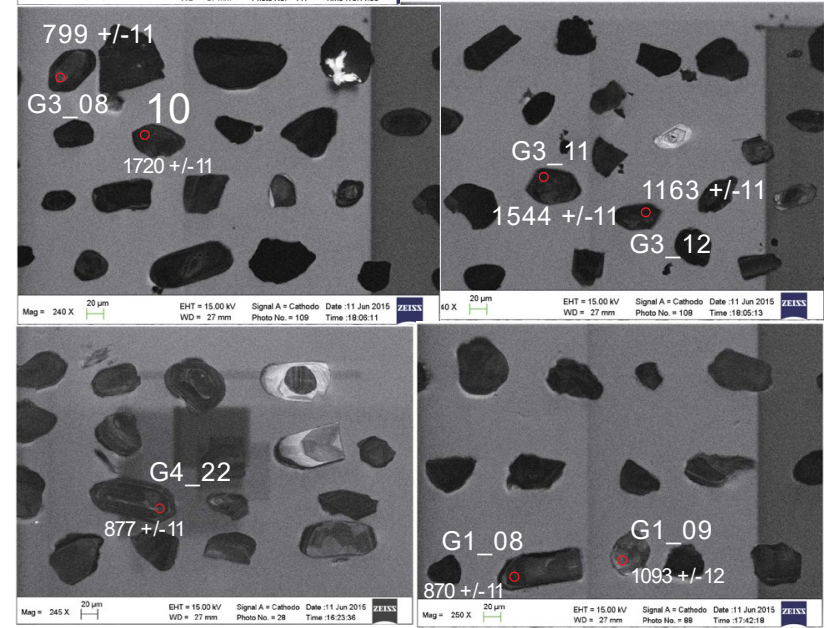

Figure 4. 

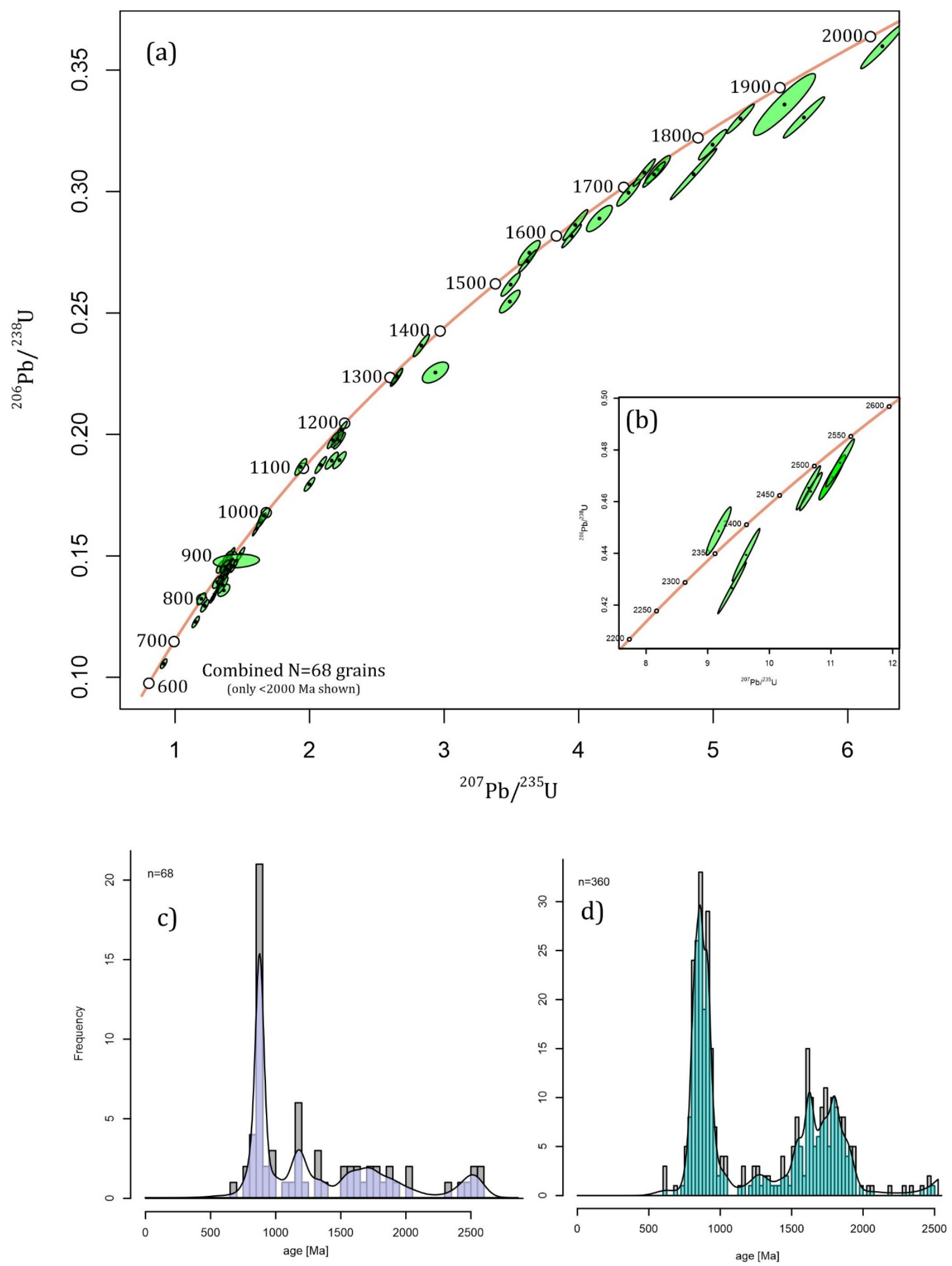

Figure 5. 
Table 1. Ages LA-ICP-MS

\begin{tabular}{|c|c|c|c|c|c|c|c|c|c|c|c|c|c|c|c|}
\hline Grain Name & ${ }^{207} \mathrm{~Pb} /{ }^{235} \mathrm{U}$ & $2 \sigma$ & ${ }^{206} \mathrm{~Pb} /{ }^{238} \mathrm{U}$ & $2 \sigma$ & Rho & $\begin{array}{l}{ }^{207} \mathrm{~Pb} /{ }^{235} \mathrm{U} \\
\text { Age (Ma) }\end{array}$ & $1 \sigma$ & $\begin{array}{l}{ }^{206} \mathrm{~Pb} /{ }^{238} \mathrm{U} \\
\text { Age (Ma) }\end{array}$ & $1 \sigma$ & $\begin{array}{c}{ }^{207} \mathrm{~Pb} /{ }^{206} \mathrm{~Pb} \\
\mathrm{Age}(\mathrm{Ma})\end{array}$ & $1 \sigma$ & $\begin{array}{l}\text { Concordant } \\
\text { age (Ma) }\end{array}$ & $\begin{array}{c}\text { Standard } \\
\text { Error }\end{array}$ & $\begin{array}{c}\% \\
\text { disc }\end{array}$ & $\begin{array}{c}206 / 238 \\
207 / 206 \% \\
\text { Disc }\end{array}$ \\
\hline Mar1-1 & 11.1477 & 1.7 & 0.47496 & 1.6 & 0.97 & 2536 & 7.9 & 2505 & 16.6 & 2560 & 3.5 & 2559 & 3 & 2.6 & -2.1 \\
\hline Mar1-2 & 3.9477 & 1.5 & 0.28169 & 1.4 & 0.96 & 1624 & 6.1 & 1600 & 9.9 & 1654 & 3.9 & 1649 & 4 & 3.4 & -3.3 \\
\hline Mar1-4 & 9.17782 & 1.8 & 0.44859 & 1.7 & 0.94 & 2356 & 8.2 & 2389 & 17.0 & 2327 & 5.3 & 2333 & 5 & -2.8 & 2.6 \\
\hline Mar1-9 & 9.62256 & 1.9 & 0.43939 & 1.9 & 0.98 & 2399 & 8.7 & 2348 & 18.7 & 2443 & 3.2 & 2439 & 3 & 4.6 & -3.9 \\
\hline Mar1-11 & 1.39983 & 1.8 & 0.14605 & 1.7 & 0.95 & 889 & 5.3 & 879 & 7.0 & 914 & 5.8 & 900 & 5 & 2.6 & -3.9 \\
\hline $\begin{array}{c}\text { Mar1-11 } \\
\text { core }\end{array}$ & 1.43921 & 1.6 & 0.14585 & 1.5 & 0.91 & 905 & 4.8 & 878 & 6.2 & 974 & 6.8 & 921 & 5 & 5.8 & -9.9 \\
\hline $\begin{array}{c}\text { Mar1-15 } \\
\text { core }\end{array}$ & 9.39409 & 2 & 0.42656 & 1.9 & 0.99 & 2377 & 9.2 & 2290 & 18.3 & 2453 & 2.5 & 2456 & 2 & 8.4 & -6.6 \\
\hline Mar1-15 rim & 5.52968 & 3.4 & 0.33583 & 3.1 & 0.92 & 1905 & 14.6 & 1867 & 25.1 & 1948 & 11.9 & 1934 & 11 & 4.1 & -4.2 \\
\hline Mar1-18 & 10.633 & 1.5 & 0.46535 & 1.5 & 0.97 & 2492 & 7.0 & 2463 & 15.4 & 2515 & 3.1 & 2512 & 3 & 2.4 & -2.1 \\
\hline Mar1-20 & 3.97499 & 1.9 & 0.28624 & 1.8 & 0.95 & 1629 & 7.7 & 1623 & 12.9 & 1637 & 5.5 & 1635 & 5 & 0.9 & -0.9 \\
\hline Mar1-23 & 2.22213 & 1.6 & 0.19739 & 1.4 & 0.89 & 1188 & 5.6 & 1161 & 7.4 & 1237 & 7.2 & 1201 & 5 & 4.1 & -6.1 \\
\hline Mar1-49 & 4.56032 & 1.5 & 0.30703 & 1.4 & 0.95 & 1742 & 6.3 & 1726 & 10.6 & 1761 & 4.3 & 1757 & 4 & 2.0 & -2.0 \\
\hline Mar1-50 & 4.48748 & 1.5 & 0.3078 & 1.5 & 0.96 & 1729 & 6.2 & 1730 & 11.4 & 1727 & 3.9 & 1728 & 4 & -0.2 & 0.2 \\
\hline Mar1-51 & 5.67435 & 2.2 & 0.33049 & 2.1 & 0.97 & 1927 & 9.5 & 1841 & 16.8 & 2022 & 4.8 & 2013 & 4 & 10.0 & -9.0 \\
\hline Mar1-53 & 2.23591 & 1.6 & 0.20193 & 1.4 & 0.92 & 1192 & 5.6 & 1186 & 7.6 & 1205 & 6.2 & 1197 & 5 & 1.1 & -1.6 \\
\hline $\begin{array}{c}\text { Mar1-53 } \\
\text { center }\end{array}$ & 2.20602 & 1.7 & 0.1981 & 1.4 & 0.82 & 1183 & 5.9 & 1165 & 7.5 & 1216 & 9.6 & 1184 & 6 & 2.4 & -4.2 \\
\hline Mar1-56 tip & 1.99896 & 1.6 & 0.17946 & 1.3 & 0.85 & 1115 & 5.4 & 1064 & 6.4 & 1216 & 8.3 & 1114 & 6 & 7.2 & -12.5 \\
\hline $\begin{array}{c}\text { Mar1-56 } \\
\text { core }\end{array}$ & 2.17417 & 1.6 & 0.19759 & 1.4 & 0.89 & 1173 & 5.6 & 1162 & 7.5 & 1192 & 7.2 & 1178 & 5 & 1.6 & -2.5 \\
\hline Mar1-58 & 4.8538 & 2.9 & 0.30717 & 2.8 & 0.99 & 1794 & 12.2 & 1727 & 21.2 & 1874 & 3.7 & 1874 & 3 & 9.4 & -7.8 \\
\hline Mar1-62 & 5.20311 & 1.6 & 0.32999 & 1.5 & 0.96 & 1853 & 6.8 & 1838 & 12.0 & 1870 & 4.1 & 1867 & 4 & 1.8 & -1.7 \\
\hline Mar1-63 tip & 10.67391 & 1.4 & 0.46391 & 1.3 & 0.96 & 2495 & 6.5 & 2457 & 13.3 & 2527 & 3.3 & 2524 & 3 & 3.3 & -2.8 \\
\hline Mar1-66 rim & 2.6503 & 1.3 & 0.22396 & 1.2 & 0.92 & 1315 & 4.8 & 1303 & 7.1 & 1334 & 4.9 & 1324 & 4 & 1.9 & -2.4 \\
\hline $\begin{array}{c}\text { Mar1-66 } \\
\text { core }\end{array}$ & 2.64637 & 1.4 & 0.22339 & 1.3 & 0.91 & 1314 & 5.2 & 1300 & 7.7 & 1336 & 5.6 & 1323 & 4 & 2.1 & -2.7 \\
\hline Mar1-72-2 & 1.2939 & 1.6 & 0.13415 & 1.6 & 0.96 & 843 & 4.6 & 812 & 6.1 & 927 & 4.7 & 885 & 4 & 9.4 & -12.5 \\
\hline Mar1-75-1 & 1.27941 & 1.4 & 0.13252 & 1.2 & 0.88 & 837 & 4.0 & 802 & 4.5 & 929 & 6.8 & 836 & 4 & 6.3 & -13.6 \\
\hline
\end{tabular}




\begin{tabular}{|c|c|c|c|c|c|c|c|c|c|c|c|c|c|c|c|}
\hline Grain Name & ${ }^{207} \mathrm{~Pb} /{ }^{235} \mathrm{U}$ & $2 \sigma$ & ${ }^{206} \mathrm{~Pb} /{ }^{238} \mathrm{U}$ & $2 \sigma$ & Rho & $\begin{array}{l}{ }^{207} \mathbf{P b} /{ }^{235} \mathbf{U} \\
\text { Age (Ma) }\end{array}$ & $1 \sigma$ & $\begin{array}{l}{ }^{206} \mathbf{P b} /{ }^{238} \mathbf{U} \\
\text { Age (Ma) }\end{array}$ & $1 \sigma$ & $\begin{array}{c}{ }^{207} \mathbf{P b} /{ }^{206} \mathbf{P b} \\
\mathrm{Age}(\mathrm{Ma})\end{array}$ & $1 \sigma$ & $\begin{array}{l}\text { Concordant } \\
\text { age (Ma) }\end{array}$ & $\begin{array}{c}\text { Standard } \\
\text { Error }\end{array}$ & $\begin{array}{c}\% \\
\text { disc }\end{array}$ & $\begin{array}{c}206 / 238 \\
207 / 206 \% \\
\text { Disc }\end{array}$ \\
\hline Mar1-83 & 1.34527 & 2 & 0.13922 & 1.7 & 0.83 & 866 & 5.8 & 840 & 6.7 & 931 & 11.5 & 862 & 6 & 4.3 & -9.7 \\
\hline Mar1-83-2 & 1.39569 & 1.5 & 0.14561 & 1.3 & 0.85 & 887 & 4.4 & 876 & 5.3 & 914 & 8.1 & 888 & 4 & 1.9 & -4.1 \\
\hline $\begin{array}{c}\text { Mar1-83 } \\
\text { core }\end{array}$ & 1.35313 & 1.9 & 0.13963 & 1.7 & 0.91 & 869 & 5.6 & 843 & 6.7 & 937 & 8.1 & 880 & 6 & 5.4 & -10.0 \\
\hline Mar1-83-3 & 1.37672 & 1.6 & 0.14339 & 1.3 & 0.83 & 879 & 4.7 & 864 & 5.3 & 918 & 9.2 & 876 & 5 & 2.5 & -5.9 \\
\hline Mar1-85 & 6.25711 & 2.1 & 0.35982 & 2.1 & 0.97 & 2012 & 9.2 & 1981 & 17.9 & 2045 & 4.6 & 2039 & 4 & 3.4 & -3.1 \\
\hline Mar1-87 & 4.99534 & 1.7 & 0.31928 & 1.6 & 0.94 & 1819 & 7.2 & 1786 & 12.5 & 1856 & 5.2 & 1846 & 5 & 3.8 & -3.7 \\
\hline $\begin{array}{c}\text { Mar1-88 } \\
\text { core }\end{array}$ & 3.62059 & 1.5 & 0.27129 & 1.4 & 0.96 & 1554 & 6.0 & 1547 & 9.6 & 1563 & 4.0 & 1561 & 4 & 1.0 & -1.0 \\
\hline Mar1-98 & 1.35479 & 2.3 & 0.13798 & 2 & 0.85 & 870 & 6.7 & 833 & 7.8 & 964 & 12.4 & 868 & 7 & 6.4 & -13.5 \\
\hline Mar1-98-2 & 1.35167 & 1.6 & 0.14046 & 1.4 & 0.87 & 868 & 4.7 & 847 & 5.6 & 922 & 8.1 & 870 & 5 & 3.8 & -8.1 \\
\hline Mar1-98-3 & 1.38956 & 2.1 & 0.14417 & 1.4 & 0.7 & 885 & 6.2 & 868 & 5.7 & 926 & 15.4 & 874 & 6 & 2.6 & -6.2 \\
\hline Mar1-98-4 & 1.41514 & 1.6 & 0.14616 & 1.3 & 0.8 & 895 & 4.8 & 879 & 5.3 & 935 & 9.9 & 892 & 5 & 2.6 & -5.9 \\
\hline $\begin{array}{c}\text { Mar1-98 } \\
\text { core }\end{array}$ & 1.38164 & 1.5 & 0.14238 & 1.3 & 0.88 & 881 & 4.4 & 858 & 5.2 & 939 & 7.3 & 884 & 5 & 4.2 & -8.7 \\
\hline Mar1-98-5 & 1.34446 & 1.9 & 0.14128 & 1.8 & 0.92 & 865 & 5.5 & 852 & 7.2 & 899 & 7.7 & 874 & 5 & 3.0 & -5.3 \\
\hline Mar1-98-6 & 1.38759 & 1.5 & 0.14438 & 1.4 & 0.89 & 884 & 4.4 & 869 & 5.7 & 920 & 7.1 & 889 & 4 & 2.8 & -5.5 \\
\hline
\end{tabular}

Notes: All isotopic ratio errors are given as 2 sigma (\%). \%Discordance $=$ discordant based on the log-ratio distance (LRD) between the measured composition and the single grain concordia composition (Vermeesch, 2021). Standard error represents the $95 \%$ confidence interval of the measured age. 
Table 2. SIMS U-Pb Analyses

\begin{tabular}{|c|c|c|c|c|c|c|c|c|c|c|c|c|c|c|c|}
\hline Grain & ${ }^{207} \mathrm{~Pb} /{ }^{235} \mathrm{U}$ & $1 \sigma$ & ${ }^{206} \mathrm{~Pb} /{ }^{238} \mathrm{U}$ & $1 \sigma$ & Rho & ${ }^{207} \mathrm{~Pb} /{ }^{235} \mathrm{U}$ & $1 \sigma$ & ${ }^{206} \mathrm{~Pb} /{ }^{238} \mathrm{U}$ & $1 \sigma$ & ${ }^{207} \mathrm{~Pb} /{ }^{206} \mathrm{~Pb}$ & $1 \sigma$ & $\begin{array}{c}\text { Concordant } \\
\text { age }\end{array}$ & $\begin{array}{l}\text { Standard } \\
\text { Error }\end{array}$ & $\%$ disc & $\begin{array}{c}206 / 238 \\
\& 207 / 206 \\
\% \text { Disc }\end{array}$ \\
\hline G1@05 & 1.41366 & 1.8 & 0.1505 & 1.6 & 0.89 & 895 & 10 & 904 & 13.2 & 872 & 16 & 892 & 10 & -1.7 & 4 \\
\hline G1@08 & 1.34218 & 2.1 & 0.1456 & 1.5 & 0.71 & 864 & 12 & 876 & 12.3 & 833 & 31 & 870 & 11 & -1.9 & 5 \\
\hline G1@09 & 1.93476 & 1.8 & 0.1866 & 1.5 & 0.82 & 1093 & 12 & 1103 & 15.2 & 1074 & 21 & 1093 & 12 & -1.4 & 3 \\
\hline$\underline{\text { G1@01 }}$ & 1.36406 & 1.8 & 0.1464 & 1.5 & 0.83 & 874 & 11 & 881 & 12.4 & 856 & 22 & 874 & 11 & -1.2 & 3 \\
\hline G1@10 & 1.39167 & 2.1 & 0.1493 & 1.5 & 0.71 & 885 & 12 & 897 & 12.6 & 857 & 31 & 891 & 11 & -1.8 & 5 \\
\hline G1@11 & 1.19576 & 2.3 & 0.1323 & 1.5 & 0.67 & 799 & 12 & 801 & 11.3 & 792 & 35 & 800 & 11 & -0.4 & 1 \\
\hline G2@02 & 1.31336 & 2.2 & 0.1392 & 1.5 & 0.70 & 852 & 12 & 840 & 11.9 & 882 & 32 & 845 & 11 & 1.9 & -5 \\
\hline G2@04 & 1.60687 & 1.6 & 0.1612 & 1.5 & 0.95 & 973 & 10 & 963 & 13.4 & 994 & 10 & 983 & 8 & 2.3 & -3 \\
\hline G2@06 & 2.16474 & 1.8 & 0.1892 & 1.5 & 0.83 & 1170 & 13 & 1117 & 15.4 & 1269 & 20 & 1171 & 13 & 7.1 & -12 \\
\hline G2@07 & 1.38502 & 1.7 & 0.1477 & 1.5 & 0.87 & 883 & 10 & 888 & 12.4 & 869 & 18 & 882 & 10 & -1.0 & 2 \\
\hline G2@12 & 1.64164 & 1.8 & 0.1646 & 1.5 & 0.84 & 986 & 11 & 982 & 13.8 & 995 & 20 & 987 & 11 & 0.6 & -1 \\
\hline G3@03 & 0.91566 & 2.2 & 0.1056 & 1.5 & 0.71 & 660 & 11 & 647 & 9.4 & 705 & 33 & 651 & 9 & 2.6 & -8 \\
\hline G3@04 & 3.48816 & 1.8 & 0.2547 & 1.5 & 0.84 & 1525 & 14 & 1463 & 19.6 & 1612 & 18 & 1543 & 14 & 7.0 & -9 \\
\hline G3@05 & 1.48682 & 1.7 & 0.1507 & 1.5 & 0.89 & 925 & 10 & 905 & 12.9 & 973 & 16 & 931 & 11 & 3.7 & -7 \\
\hline G3@08 & 1.22084 & 2.0 & 0.1294 & 1.6 & 0.78 & 810 & 11 & 784 & 11.7 & 882 & 26 & 799 & 11 & 4.4 & -11 \\
\hline G3@10 & 4.37119 & 1.6 & 0.2995 & 1.5 & 0.91 & 1707 & 14 & 1689 & 22.3 & 1729 & 12 & 1720 & 11 & 2.1 & -2 \\
\hline G3@11 & 3.49425 & 1.7 & 0.2617 & 1.5 & 0.90 & 1526 & 13 & 1499 & 20.1 & 1564 & 13 & 1544 & 11 & 3.5 & -4 \\
\hline G3@12 & 2.08303 & 1.7 & 0.1874 & 1.5 & 0.90 & 1143 & 12 & 1107 & 15.4 & 1212 & 14 & 1163 & 11 & 6.0 & -9 \\
\hline G3@15 & 1.15383 & 1.9 & 0.1228 & 1.6 & 0.81 & 779 & 10 & 747 & 11.0 & 873 & 23 & 766 & 11 & 5.8 & -14 \\
\hline G3@16 & 2.83048 & 1.7 & 0.2366 & 1.6 & 0.92 & 1364 & 13 & 1369 & 19.6 & 1355 & 13 & 1360 & 11 & -0.8 & 1 \\
\hline G3@17 & 4.58743 & 1.7 & 0.3091 & 1.5 & 0.90 & 1747 & 14 & 1736 & 23.0 & 1760 & 13 & 1754 & 12 & 1.2 & -1 \\
\hline G4@02 & 11.02106 & 1.6 & 0.4694 & 1.5 & 0.95 & 2525 & 15 & 2481 & 31.3 & 2560 & 9 & 2555 & 8 & 3.6 & -3 \\
\hline G4@05 & 4.15409 & 1.9 & 0.2889 & 1.5 & 0.81 & 1665 & 15 & 1636 & 22.1 & 1702 & 20 & 1672 & 15 & 2.9 & -4 \\
\hline G4@11 & 1.66159 & 2.0 & 0.1666 & 1.5 & 0.76 & 994 & 12 & 993 & 13.8 & 995 & 26 & 994 & 12 & 0.1 & 0 \\
\hline G4@16 & 2.93509 & 2.7 & 0.2255 & 1.6 & 0.58 & 1391 & 20 & 1311 & 18.5 & 1516 & 42 & 1337 & 18 & 9.6 & -14 \\
\hline G4@17 & 3.63257 & 1.8 & 0.2748 & 1.5 & 0.83 & 1557 & 15 & 1565 & 21.0 & 1545 & 19 & 1554 & 14 & -0.9 & 1 \\
\hline
\end{tabular}




\begin{tabular}{|c|c|c|c|c|c|c|c|c|c|c|c|c|c|c|c|}
\hline Grain & ${ }^{207} \mathrm{~Pb} /{ }^{235} \mathrm{U}$ & $1 \mathrm{~s}$ & ${ }^{206} \mathrm{~Pb} /{ }^{238} \mathrm{U}$ & $1 \mathrm{~s}$ & Rho & ${ }^{207} \mathrm{~Pb} /{ }^{235} \mathrm{U}$ & $1 \mathrm{~s}$ & ${ }^{206} \mathrm{~Pb} /{ }^{238} \mathrm{U}$ & $1 \mathrm{~s}$ & ${ }^{207} \mathrm{~Pb} /{ }^{206} \mathrm{~Pb}$ & $1 \mathrm{~s}$ & $\begin{array}{l}\text { Concordant } \\
\text { age }\end{array}$ & $\begin{array}{c}\text { Standard } \\
\text { Error }\end{array}$ & $\begin{array}{c}\% \\
\text { disc }\end{array}$ & $\begin{array}{c}\text { 206/238 } \\
\& 207 / 206 \\
\text { \% Disc }\end{array}$ \\
\hline G4@17 & 3.63257 & 1.8 & 0.2748 & 1.5 & 0.83 & 1557 & 15 & 1565 & 21.0 & 1545 & 19 & 1554 & 14 & -0.9 & 1 \\
\hline G4@18 & 1.35665 & 2.02 & 0.1418 & 1.51 & 0.75 & 870 & 12 & 855 & 12.1 & 910 & 28 & 863 & 11 & 2.5 & -6 \\
\hline G4@21 & 1.45558 & 9.62 & 0.1479 & 1.55 & 0.16 & 912 & 58 & 889 & 12.9 & 968 & 194 & 890 & 13 & 3.8 & -8 \\
\hline G4@22 & 1.37391 & 2.08 & 0.1456 & 1.5 & 0.72 & 878 & 12 & 876 & 12.3 & 882 & 30 & 877 & 11 & 0.3 & -1 \\
\hline
\end{tabular}

Notes: All isotopic ratio errors are given as 1 sigma (\%). \%Discordance= discordant based on the log-ratio distance (LRD) between the measured composition and the single grain concordia composition (Vermeesch, 2021). Standard error represents the $95 \%$ confidence interval of the measured age. 